\section{Bàn luận về yếu tố liên quan đến kết quả điều trị \\ - Bệnh nhân có rối loạn đông máu có tỉ lệ tử} vong cao hơn có ý nghĩa thống kê với $\mathrm{p}<0,05$. Các xét nghiêm đánh giá tình trang đông máu giúp đánh giá, tiên lượng bệnh cũng như kếtquả điêu trị, hỗ trợ có một cái nhìn đúng về tình mức đô bênh và can thiệp chữa trị kịp thời[1]. Nghiên cứu của tôi cũng tương tự như của Tseng và cộng sự vào năm 2007 cho thấy những bệnh nhân có rối loạn đông máu có nguy cơ tử vong cao có ý nghĩa thống kê với $p<0,05[7]$

- Bệnh nhân thở máy có tỉ lệ tử vong cao hơn có ý nghĩa thống kê với $p<0,05$. Bệnh nhân sốc nhiểm khuẩn thường có tình trạng suy hô hấp từ trước và cần hố trợ hô hấp khi nhập viện. Bệnh nhân cần thở máy xâm nhập là bệnh nhân có tình trạng rối loạn hô hấp, rối loạn ý thức, rối loạn huyết động nặng nề, cùng với đó là những nguy cơ do thở máy như nhiễm khuẩn thứ phát, nhiễm khuẩn bệnh viện làm tăng nguy cơ tử vong của bệnh nhân

\section{KẾT LUẬN}

Nghiên cứu trên 47 bênh nhân sốc nhiễm khuẩn điều trị tại bệnh viện Trung ương Thái Nguyên từ tháng 7 năm 2019 đến tháng 7 năm 2020. Tôi có một số kết luận sau:

- Bênh nhân tuổi càng cao càng có nguy cơ sốc nhiễm khuẩn cao hơn.

- Nam giới có tỉ lệ mắc bệnh cao hơn nữ giới.

- Ổ nhiếm khuẩn tiên phát thường gặp nhất là cơ quan hô hấp

- Tỉ lệ cấy máu dương tính thấp. Chủ yếu là vi khuẩn gram âm.

- Có mối liên quan có ý nghĩa thống kê với độ tin cậy 95\% giữa tình trạng rối loạn đông máu, thở máy xâm nhập và kết cục ra viện ở bệnh nhân sốc nhiễm khuẩn.

TÀI LIỆU THAM KHẢO

1. Angus DC. L-ZW, Lidicker J. et al (2001). "Epidemiology of severe sepsis in the unite States: analysis of incidence, outcome, and associated cost of care", Crit Care Med, 29, pp.1303-1310, pp.

2. Chertoff J. CM, Garcia B., et al (2015). Lactate kinetics in sepsis and septic shock: a review of the literature and rationale for further research. J Intensive Care, 3(39), 1-4, pp.

3. Vũ Hải Yến (2012). Nghiên cứu đăc điểm lâm sàng- cận lâm sàng và kểt quả của liệuu pháp điều tri sớm theo muc tiêu ở bệnh nhân sốc nhiếm khuẩn. Luận văn thạc sỹ y học, Trường Đại học Y Hà Nô̂i. Tr 34-55.

4. Phạm Quốc Dũng LTVH, Nguyễn Mạnh Dũng (2019), "Đặc điểm lâm sàng, cận lâm sàng và nồng độ môt số cytokine ở bệnh nhân sốc nhiếm khuẩn", Tạp chí Y Dược lâm sàng 108. Tâp 14 - số 4, pp.

5. Pham Tuấn Đức (2011). Đánh giá thay đổi vân chuyển ôxy và tiêu thụ ôxy trên bệnh nhân sốc nhiểm khuẩn. Luân văn thạc sỹ y học $T Ð$, pp.

6. Trân Minh Điến (2010). Nghiên cứu kết quả điều trị và một số yếu tố tiên lượng tứ vong trong sốc nhiễm khuẩn trẻ em. Luânn án tiến sỹ $Y$ học. Trường Đai hoc Y Hà Nôii. Tr 55-87

7. Tseng YC. WJ, Wu FLL. et al. (2007), "Prognosis of adult patients with bacteremia caused by extensively resistant Acinetobacter baumannii", Diagnostic Microbiology and Infectious Disease, 59, pp.181-190, pp.

8. Mai Vắn Cường (2011). Nghiên cứu sự liên quan giữa áp lực tĩnh mach trung tâm và áp lực mao mạch phổi bít ở bệnh nhân sốc nhiếm khuẩn và sốc tim. Luận văn tốt nghiệp bác sĩ nội trú bệnh viện. Trường Đại học Y Hà Nội. Tr 29-53.

9. Vincent $J L$ SY, Sprung $C L$, Ranieri VM, Reinhart K, Gerlach H, Moreno R, Carlet J, Le Gall JR, Payen D (2006). Sepsis Occurrence in Acutely Ill Patients Investigators. Sepsis in European intensive care units: results of the SOAP study. Crit Care Med. 34:344-53, pp.

\title{
CHẤT LƯợNG CUỘC SỐNG CỦA NGƯờI BÊNH UNG THƯ VÚ VÀ MộT Số YẾU TỐ LIÊN QUAN TẠI BỆNH VIỆN ĐA KHOA KIÊN GIANG, NĂM 2020
}

\section{TÓM TẮT.}

\author{
${ }^{1}$ Trường ĐH Thăng Long \\ ${ }^{2}$ Bênh viên $Đ K$ Kiên Giang \\ Chịu trách nhiệm chính: Nguyễn Phi Hải \\ Email: nguyenphihai@gmail.com \\ Ngày nhận bài: 23.10.2020 \\ Ngày phản biện khoa học: 30.11 .2020 \\ Ngày duyệt bài: 10.12.2020
}

\section{Nguyễn Phi Hải ${ }^{1,2}$, Bùi Hoài Nam ${ }^{1}$}

Nghiên cứu mô tả cắt ngang thực hiện trên 138 người bênh taii bênh viên đa khoa Kiên Giang từ tháng 01/2020 đến 6/2020 trên bệnh nhân ung thư vú. Mục tiêu làm ô tả đặc điểm lâm sàng, cận lâm sàng của người bệnh ung thư vú. Phân tích chất lượng cuộc sống liên quan đến điều trị, chăm sóc và một số yểu tố liên quan khác. Số liệu thu thập được là bảng theo dõi điêu dưỡng chăm sóc bênh nhân như tỷ lệnữ cao hơn nam, tỷ lẹ cao nhất ở nhóm tuổi $40-59$ tuổi (68.8\%), tiếp đ̛ến nhóm tuổi $>=60$ tuổi $(27.5 \%)$, tỷ lệ thấp nhất thuộc nhóm tuổi <=39 tuổi (3.6\%). Tỳ lệ 
người bênh không có tiền sử gia đình mắc bệnh ung thư vú là $97.2 \%$, có là $2.9 \%$. Tỷ lệ người bệnh ở giai đoạn sớm là 40,6\%, trong đó giai đoạn I là 11,6\%, giai đoạn II là $29,0 \%$. Tỷ lệ người bệnh ở giai đoạn muộn là $59,4 \%$, trong đó giai đoạn III là $55,8 \%$ và giai đoạn IV là 3,6\%. Tỷ lệ người bệnh phẫu thuật cắt tuyến vú triệt căn là $87,0 \%$, phẫu thuật bảo tồn $9,4 \%$ và không phẫu thuật được là 3,6\%. Tỷ lệ người bệnh hoá trị chiếm 44,2\%; Xạ trị chiếm $39,9 \%$ và khổng hóa trị - xạ trị chiếm $15.9 \%$. Tỷ lệ người bệnh có cải thiện là $77,5 \%$; Giữ nguyên là $18,8 \%$ và tiến triển năng là $3,7 \%$. CLCS chung với kết quả điều trị chăm sóc có sự khác biệt có ý nghĩa thống kê với $p<0.05$; Giới tính với CLCS về tâm lý - cảm xúc có sự khác nhau và có ý nghĩa thống kê $(p<0,05)$. Sức khỏe tổng quát với CLCS chung có ý nghĩa thống kê $(p<0,05)$.CLCS người bệnh có và không có hoá trị, xạ trị với CLCS chung là khác nhau có ý nghĩa thống kê $(p<0,05)$.

Tư khóa: Chất lượng cuộc sống, ung thư vú, chăm sóc bệnh nhân

\section{SUMMARY \\ QUALITY OF LIFE OF PEOPLE WITH CANCER CANCER AND A NUMBER OF RELATED FACTORS IN KIEN GIANG MULTIPLAYER HOSPITAL, 2020}

Cross-sectional descriptive studies performed on 138 patients at Kien Giang general hospital from January 2020 to June 2020 on breast cancer patients. The goal is to describe the clinical and subclinical characteristics of a person with breast cancer. Quality of life analysis related to treatment, care and some other related factors. The collected data is the monitoring table for nursing care, such as the percentage of women is higher than that of men, the highest rate is in the $40-59$ age group $(68.8 \%)$, age group $>=60$ years $27.5 \%$, age group $<=39$ years old $(3.6 \%)$. The proportion of patients without a family history of breast cancer was $97.2 \%$ and $2.9 \%$. the early stage is $40.6 \%$, of which the first stage is $11.6 \%$, the second stage is $29.0 \%$. The proportion of patients in the early stage is $40.6 \%$, of which the first stage is $11.6 \%$, the second stage is $29.0 \%$. The rate of patients in late stage is $59.4 \%$, in which stage III is $55.8 \%$ and stage IV is $3.6 \%$. The rate of patients with radical mastectomy is $87.0 \%$, conservative surgery $9.4 \%$ and non-surgical $3.6 \%$. The rate of chemotherapy patients accounts for $44.2 \%$; Radiation therapy accounts for $39.9 \%$ and no chemotherapy radiotherapy accounts for $15.9 \%$. The rate of patients with improvement is $77.5 \%$; Steady at $18.8 \%$ and progression at $3.7 \%$. CLCS with results of care treatment has the statistically significant difference with $p<0.05$; Sex with quality of psychology - emotion was different and statistically significant $(p<0.05)$.

Key words: Quality of life, ostomy, patient care.

\section{I. ĐẶT VẤN ĐỀ}

Ung thư vú (UTV) là loại ung thư thường gặp nhất và là nguyên nhân gây tử vong thứ 2 sau ung thư phổi. Tại Việt Nam, theo nghiên cứu gánh nặng bệnh ung thư và chiến lược phòng chống ung thư quốc gia đến năm 2020 cho thấy UTV là bệnh có tỷ lệ mới mắc cao nhất trong các ung thư ở nữ giới. Tỷ lệ mới mắc chuẩn theo tuổi năm 2010 ước tính là 28,1/100.000 phụ nữ. Mặc dù tỷ lệ UTV có xu hướng tăng trong những năm gần đây, nhưng tỷ lệ tử vong do bệnh đã từng bước được cải thiện nhờ các thành tựu trong phòng bệnh, phát hiện sớm bệnh, chẩn đoán và điêu trị. Mục tiêu của điều trị ung thư vú là giảm tái phát, tăng thời gian sông còn và cải thiện chất lượng cuộc sống của bệnh nhân. Hiện nay, phương pháp điều trị UTV là một chiến lược điều trị đa mô thức: phẫu thuật, hóa trị, xạ trị, sinh học phân tử... Phẫu trị ngay từ đầu rất quan trọng để đạt kết quả điều trị tốt nhất, cho được các yếu tố tiên lượng trung thực và khách quan nhất giúp cho điều trị hỗ trợ tiếp theo. Do đó công tác chăm sóc làm giảm các tác dụng phụ của điều trị cũng như giúp người bệnh nhanh chóng ổn định tinh thần, trở về với cuộc sống bình thường là rất quan trọng Hiện nay, nghiên cứu về CLCS và vấn đề chăm sóc người bệnh ung thư vú ở Bệnh viện Đa khoa (BVĐK) Kiên Giang là gần như chưa có, vì vậy chúng tôi tiến hành nghiên cứu với tên đề tài "Chất lượng cuộc sông của người bệnh ung thư vú và một số yêu tố liên quan tại Bệnh Viện Đa Khoa Kiên Giang, năm 2020"Với 2 mục tiêu cụ thể như sau:

1. Mô tả đặc điểm lâm sàng, cận lâm sàng của người bệnh ung thư vú tại Bệnh viện Đa khoa Kiên Giang.

2. Phân tích chất lượng cuộc sông liên quan đến điều trị, chăm sóc và một số yếu tố liên quan khác.

\section{II. ĐốI TƯợiNG VÀ PHƯƠNG PHÁP NGHIÊN CỨU \\ 1. Đối tượng nghiên cứu}

Tiêu chuấn lứa chọn: người bệnh ung thư vútại khoa ung bướu bệnh viện đa khoa Kiên Giang.

Tiêu chuẩn loại trừ: Thân nhân - bệnh nhân không đồng ý tham gia nghiên cứu.

Thời gian: từ tháng 01/2020 đến 6/2020.

2. Thiết kế nghiên cứu: Nghiên cứu mô tả cắt ngang

3. Cỡ mẫu: Tổng số 138 bệnh nhân ung thư' vú tại bệnh viện đa khoa Kiên Giang

4. Biến số NC: Tuổi, giới,trình độ học vấn, nghề nghiệp thời gian mắc bệnh, bệnh lý kèm theo, loại phâuu thuật, hoạt động chăm sóc.

5. Xử lý số liệu: Phân tích, xử lý bằng phần mềm SPSS 20.0 để tính tỷ lệ phần trăm, phân tích đơn biến các yếu tố có nguy cơ gia tăng biến chứng, khác biệt có ý nghĩa thống kê khi ( $\mathrm{p}$ $<0,05)$. 


\section{KẾT QUẢ NGHIÊN CứU}

1. Đặc điểm chung của đối tượng nghiên cưuu

Bảng 1. Phân bố đối tượng nghiên cứu theo giới, tuổi

\begin{tabular}{|c|c|c|}
\hline Giới & n (138) & Tỷ lệ (\%) \\
\hline Nam & 2 & 1.4 \\
\hline Nũ̃ & 136 & 98.6 \\
\hline \multicolumn{3}{|c|}{ Tuổi của đối tượng nghiên cứu } \\
\hline$<=39$ & 5 & 3.6 \\
\hline $40-59$ & 95 & 68.8 \\
\hline$>=60$ & 38 & 27.5 \\
\hline \multicolumn{3}{|c|}{ Nghề nghiệp đối tượng nghiên cứu } \\
\hline Nồng dần & 29 & 21.0 \\
\hline Cán bộ, công nhân viên & 8 & 5.8 \\
\hline Kinh doanh & 6 & 4.3 \\
\hline Hưu trí & 2 & 1.4 \\
\hline Lao động tự do & 93 & 67.4 \\
\hline \multicolumn{3}{|c|}{ Trình độ học vấn đối tượng NC } \\
\hline Không biết chữ & 19 & 13.8 \\
\hline Tiểu học & 39 & 28.3 \\
\hline THCS & 49 & 35.5 \\
\hline THPT & 23 & 16.7 \\
\hline Trung học & 2 & 1.4 \\
\hline CĐ, Đại học & 6 & 4.3 \\
\hline
\end{tabular}

Nhận xét: Tỷ lệ nam giời là $1.4 \%$, nữ giới là $98.6 \%$. Tuổi từ 40-59 cao nhất $68,8 \%$, tiếp đến tuổi >=60 chiếm $27.5 \%$, thấp nhất nhóm tuổi $<=39$ tuổi chiếm 3.6\%; Nghề nghiệp nông dân chiếm $21 \%$, Cán bộ công nhân viên là $5.8 \%$, hưu trí $1.4 \%$, Lao động tự do nhiều nhấtchiếm $67.4 \%$. Tình trạng hồn nhẩn chủ yếu đã kết hôn chiếm tỷ lệ 95,7\%; Tỷ lệ trình độ học vấn tiểu học là $28.3 \%$, trung học cơ sở $1.4 \%$, Cao đẳng và đại học $4.3 \%$, Không biết chữ chiếm $13.8 \%$, trung học phổ thông chiếm 16.7\%.

\section{Bảng 2. Vị trí khôi u}

\begin{tabular}{|c|c|c|}
\hline Loại bệnh & n & Tỷ lệ $\%$ \\
\hline $1 / 4$ bên trong & 30 & 21,7 \\
\hline $1 / 4$ bên ngoài & 73 & 52,9 \\
\hline
\end{tabular}

\begin{tabular}{|c|c|c|}
\hline $1 / 4$ dưới trong & 6 & 4,3 \\
\hline 1/4 dưới ngoài & 16 & 11,6 \\
\hline Trung tâm & 11 & 8,0 \\
\hline Đa ố & 2 & 1,4 \\
\hline
\end{tabular}

Nhân xét: Tỷ lệ ở các vị trí của U khác nhau, dao động từ 1,4\%-52,9\%. Trong đó, vị trí $1 / 4$ bên ngoài chiếm tỷ lệ cao nhất là $52,9 \%$, Đa ổ chiếm tỷ lệ thấp nhất là $1,4 \%$.

Bảng 3. Đặc điểm tốn thương

\begin{tabular}{|c|c|c|c|}
\hline \multicolumn{2}{|c|}{ Tính chất } & n & Tỷ lệ \% \\
\hline \multirow{2}{*}{ Di động } & Còn di động & 86 & 62,3 \\
\cline { 2 - 4 } & Cố định & 52 & 37,7 \\
\hline \multirow{2}{*}{ Đỏ da } & Có & 42 & 30,4 \\
\cline { 2 - 4 } & Không & 96 & 69,6 \\
\hline \multirow{2}{*}{$\begin{array}{c}\text { Phù da, sần } \\
\text { da cam }\end{array}$} & Có & 29 & 21,0 \\
\hline \multirow{2}{*}{ Loét da } & Kống & 109 & 79,0 \\
\cline { 2 - 4 } trên U & Không & 73 & 52,9 \\
\hline \multirow{2}{*}{ Tụt nắm vú } & Có & 25 & 47,1 \\
\cline { 2 - 4 } & Không & 113 & 81,9 \\
\hline
\end{tabular}

Nhân xét: Tỷ lê U còn di động là 62,3\%, tỷ lệ U cố định là $37,7 \%$, Tỷ lệ Có đỏ da là 30,4\%; Tỷ lệ Phù da, sần da cam là $21,0 \%$; Tỷ lệ Loét da trên u là $52,9 \%$; Tỷ lệ Tụt núm vú là $18,1 \%$.

Bảng 4. Đặc điểm thụ thể nội tiêt

\begin{tabular}{|c|c|c|c|}
\hline \multicolumn{2}{|c|}{ Thụ thể nội tiết } & n & Tỷ lệ \% \\
\hline \multirow{2}{*}{ ER } & Dương tính & 63 & 45.7 \\
\cline { 2 - 4 } & Âm tính & 75 & 54.3 \\
\hline \multirow{2}{*}{ PR } & Dương tính & 59 & 42.8 \\
\cline { 2 - 4 } & Âm tính & 79 & 57.2 \\
\hline \multirow{2}{*}{ HER- } & Dương tính & 65 & 47.1 \\
\cline { 2 - 4 } 2/neu & Âm tính & 73 & 52.9 \\
\hline
\end{tabular}

Nhân xét: Tỷ lệ người bệnh có thụ thể ER dương tính là $45,7 \%$, PR dương tính là $42,8 \%$ và HER-2/Neu dương tính là 47,1\%

2. Chất lượng cuộc sống, một số yếu tố liên quan đến điêu trị - chăm sóc và một số yếu tố khác

\section{Bảng 5. Hoạt động chăm sóc điều dướng}

\begin{tabular}{|c|c|c|c|}
\hline Biến số & $\begin{array}{c}\text { Có } \\
\text { n (\%) }\end{array}$ & $\begin{array}{l}\text { Không } \\
\text { n (\%) }\end{array}$ & $\begin{array}{l}\text { Tống } \\
\text { n (\%) }\end{array}$ \\
\hline \multicolumn{4}{|c|}{ Chăm sóc cơ bản } \\
\hline Dấu hiệu sinh tôn & $138(100,0)$ & $0(0)$ & $138(100,0)$ \\
\hline Sử dụng và tác dụng phụ của thuốc & $136(98,6)$ & $2(1,4)$ & $138(100,0)$ \\
\hline Thực hiện các y lệnh đầy đủ, kịp thời & $137(99,3)$ & $1(0,7)$ & $138(100,0)$ \\
\hline \multicolumn{4}{|c|}{ Giáo dục sức khoẻ } \\
\hline $\begin{array}{l}\text { Động viên, trấn an bệnh nhân để bệnh nhân an tâm } \\
\text { điều trị. }\end{array}$ & $128(92,8)$ & $10(7,2)$ & $138(100,0)$ \\
\hline Hướng dần vệ sinh cá nhân sạch sẽ $\geq 2$ lần/tuần & $119(86,2)$ & $19(13,8)$ & $138(100,0)$ \\
\hline Hướng dần chế độ đảm bảo dinh dưỡng $\geq 2$ lần/tuần & $132(94,9)$ & $6(5,1)$ & $138(100,0)$ \\
\hline
\end{tabular}


Nhận xét: Tỷ lệ người bệnh được theo dõi dấu hiệu sinh tồn là $100.0 \%$, theo dõi Sử dụng và tác dụng phụ của thuốc là 98,6\%, thực hiện các y lệnh đầy đủ, kịp thời là 99,3\%; Tỷ lệ người bện được động viên, trấn an bệnh nhân để bệnh nhân an tâm điều trị $\geq 2$ lần/tuần là $92,8 \%$, hướng dẫn vệ sinh cá nhân sạch sẽ $\geq 2$ lần/tuần là $86,2 \%$ và hướng dẫn chế độ đảm bảo dinh dưỡng $\geq 2$ lần/tuần là $94,9 \%$.

Bảng 6. Điểm CLCS chung

\begin{tabular}{|c|c|c|c|c|}
\hline \multirow{2}{*}{\begin{tabular}{|c|} 
BSNC \\
Điểm CLCS chung \\
\end{tabular}} & Trung bình & \multicolumn{2}{|c|}{ SD } & \multirow{2}{*}{ S.E } \\
\hline & 61,83 & \multicolumn{2}{|c|}{12,68} & \\
\hline \multicolumn{5}{|c|}{$\begin{array}{l}\text { Nhân xét: Điếm trung bình CLCS Chung là } 61,83 \pm 12,68 \\
\text { Bảng 7. Mối liên quan giứa CLCS chung và } 6 \text { khía cạch của CLCS với kêt quả điều trị và } \\
\text { chăm sóc }\end{array}$} \\
\hline \multirow{2}{*}{ Các biến số } & \multirow{2}{*}{$\begin{array}{l}\text { Kết quả điều trị } \\
\text { và chăm sóc }\end{array}$} & \multicolumn{2}{|c|}{ Điểm CLCS } & \multirow[b]{2}{*}{$\mathbf{p}$} \\
\hline & & Giá tri TB & SD & \\
\hline \multirow{3}{*}{ Hoạt động thể lực } & Có cải thiện & 82,86 & 12,19 & \multirow{2}{*}{0,000} \\
\hline & Giữ nguyền & 50,51 & 18,00 & \\
\hline & Tiến triển nặng & 21,33 & 5,58 & 0,000 \\
\hline \multirow{3}{*}{ Vai trò xã hội } & Có cải thiện & 58,87 & 21,02 & \multirow{2}{*}{0,017} \\
\hline & Giữ nguyền & 47,43 & 25,25 & \\
\hline & Tiến triến năng & 30,00 & 7,45 & 0,004 \\
\hline \multirow{3}{*}{ Khả năng nhận thức } & Có cải thiên & 77,41 & 17,17 & \multirow{2}{*}{0,000} \\
\hline & Giữ nguyền & 55,13 & 16,84 & \\
\hline & Tiến triển năng & 26,67 & 9,13 & 0,000 \\
\hline \multirow{3}{*}{ Tâm lý- cảm xúc } & Có cải thiện & 61,19 & 17,29 & \multirow{2}{*}{0,143} \\
\hline & Giữ nguyên & 55,49 & 20,47 & \\
\hline & Tiến triến nặng & 43,81 & 3,98 & 0,033 \\
\hline \multirow{3}{*}{ Khó khăn tài chính } & Có cải thiện & 55,76 & 23,24 & \multirow{2}{*}{0,90} \\
\hline & Giữ nguyền & 55,13 & 22,98 & \\
\hline & Tiến triển nặng & 53,33 & 18,26 & 0,810 \\
\hline \multirow{3}{*}{ Sức khỏe tổng quát } & Có cải thiện & 84,22 & 9,98 & \multirow{2}{*}{0,000} \\
\hline & Giữ nguyền & 62,35 & 12,34 & \\
\hline & Tiến triển nặng & 28,48 & 6,28 & 0,000 \\
\hline \multirow{3}{*}{ CLCS Chung } & Có cải thiện & 67,21 & 7,61 & \multirow{3}{*}{0,000} \\
\hline & Giữ nguyên & 45,51 & 6,76 & \\
\hline & Tiến triển nặng & 31,67 & 6,97 & \\
\hline
\end{tabular}

Nhận xét: CLCS chung với kết quả điều trị chăm sóc có sự khác biệt có ý nghĩa thống kề với $\mathrm{p}<0.05$. Đa số điểm trung bình CLCS của các khía cạnh và giữa các kết quả điều trị và chăm sóc khác nhau, có xu hướng giảm dần và có ý nghĩa thống kê. Tuy nhiên, Khía cạnh Tâm lý- cảm xúc, điểm CLCS có liên quan với đến kết quả điều trị nhưng sự khác nhau giữa có cải thiện và Giữ nguyên chưa có ý nghĩa thống kê $(p=0,143>0,05)$. Khía cạnh Khó khăn tài chính, chưa thấy CLCS của người bệnh có liên quan với đến kết quả điêu trị $(p>0,05)$.

\section{BÀN LUẬN}

Tỷ lệ nữ giới là $98.6 \%$, nam giới là $1.4 \%$ tỉ lệ nữ mắc cao hơn nam kết quả nghiên cứu của chúng tôi tương đồng với kết quả của Đố Thị Kim Anh[1]. Tỷ lệ giữa các nhóm tuổi là khác nhau, nhóm 40-59 chiếm tỷ lệ cao nhất là
$58.8 \%$, nhóm tuổi <=39 chiếm tỷ lệ thấp nhất (3.6\%). Nghiên cứu của chúng tôi tương đồng với kết quả về độ tuổi của nghiên cứu Đỗ Thị Kim Anh[1]. Tỷ lệ giữa các nghề của đối tượng nghiên cứu là khác nhau, dao động từ $1.4 \%$ $67.4 \%$. Trong đó, tỷ lệ hưu trí thấp nhất là $1.4 \%$, cao nhất là nghề lao động tự do chiếm $67.4 \%$, tương đồng với nghiên cứu Bùi Diệu[2], thấp hơn nghiên cứu củaNguyễn Văn Chủ[3], có thể lý giải được sự thấp hơn này do người dân tại Kiên Giang họ đều có nghề nghiệp làm nông nên tỉ lệ nông dân chiếm đa số. Tỳ lệ các trình độ học vấn là khác nhau, dao động từ $1.4 \%$ $35.5 \%$. Trong đó trình độ trung học chiếm tỷ lệ thấp nhất là $1.4 \%$, nhóm THCS chiếm tỷ lệ cao nhất là $35.5 \%$. Có thể lý giải rằng tỉ lệ nghiên cứu của chúng tôi cũng gần như tương đồng với các nghiên cứu của Bùi Diệu[2], do trình độ học vấn thấp nên công việc của nhóm nông dân, 
nhóm nội trợ và nhóm lao động tự do thường là những công việc chân tay. Có thể sự vất vả trong công việc, kinh tế không ổn định dẫn đến lối sống tiêu cực. ở nhóm lao động trí óc công việc chủ yếu là phải suy nghĩ, áp lực trong công việc nhiều, không khám sức khỏe định kỳ đây cũng là nguy cơ dẫn đến bệnh sinh.

Vị trí U của đối tượng nghiên cứu của chúng tôi khác nhau, dao động từ 1,4\%-52,9\%. Trong đó, vị trí $1 / 4$ bên ngoài chiếm tỷ lệ cao nhất là $52,9 \%$, Đa ổ chiếm tỷ lệ thấp nhất là $1,4 \%$. Kết quả của chúng tôi tương đồng với kết quả của Từ Quốc Hiệu[5]. Khối u ở vị trí $1 / 4$ trên ngoài thường gặp nhất, chiếm đa số, tiếp đến là $1 / 4$ trên trong, có một số ít trường hợp ở vị trí trung tâm sát núm vú và có 1 trường hợp đa ổ. Hay gặp vị trí $1 / 4$ trên ngoài do thể tích mô vú ở vùng này cao nhất. Về phân bố vị trí u tương tự như trong các nghiên cứu khác. Vú trái gặp với tỷ lệ cao hơn không có sự khác biệt so với các nghiên cứu Đố Thị Kim Anh [1]. Chúng tôi quan tâm theo dõi đến các biến cố tim mạch ở các bệnh nhân ung thư vú trái và có chỉ định xạ trị trên những bệnh nhân truyền trastuzumab.

Kết quả nghiên cứu của chúng tôi thây tỷ lệ $U$ còn di động là $62,3 \%$; tỷ lệ $U$ cố định là $37,7 \%$; Tỷ lệ có đỏ da là 30,4\%; Tỷ lệ phù da, sân da cam là 21,0\%; Tỷ lể Loét da trên u là $52,9 \%$; Tỷ lệ tụt núm vú là $18,1 \%$ khá tương đồng với kết quả của Bùi Diệu[2]. Đối với những người khác, tập trung vào quản lý các cơn đau và cải thiện chất lượng cuộc sống lại là mục tiêu điều trị tại thời điểm này

Kết quả nghiên cứu của chúng tôi có tỷ lệ người bệnh có thụ thể ER dương tính là 45,7\%, $\mathrm{PR}$ dương tính là $42,8 \%$ và $\mathrm{HER}-2 / \mathrm{Neu}$ dương tính là $47,1 \%$ khá tương đồng với kết quả của Linh Thi Tu Nguyen[4]. Tỷ lệ TTNT dương tính trên bệnh nhân Her 2 dương tính ngược với tỷ lệ TTNT dương tính trong quần thể bệnh nhân UTV nói chung. Tình trang TTNT là một yếu tố tiên lượng độc lập trong UTV, nhóm bệnh nhân có Her 2 dương tính có tỷ lệ TTNT âm tínhcao.

Tỷ lệ người bênh được theo dõi dấu hiệu sinh tồn là $100.0 \%$, theo dỗi sử dụng và tác dụng phụ của thuốc là $98,6 \%$, thực hiện các y lệnh đây đủ, kịp thời là 99,3\%. Kết quả nghiên cứu của chúng tôi tương đồng với kết quả của Từ Quốc Hiệu[5]. Lý giải trường hợp này quá trình theo dõi dấu hiệu sinh tồn được diển ra hằng ngày trong thời gian nằm viện giúp người điêu dưỡng phát hiện kịp thời các diễn biến bất thường của người bênh bênh nắm được tình trạng bệnh của mình và theo dõi cách sử dụng thuốc, tập luyện các tư thế giảm đau cũng như cách tự chăm sóc bản thân trong thời gian nằmviện, người điều dưỡng hàng ngày chăm sóc người bệnh cần thể hiện kỹ năng giao tiếp tốt với người bệnh, điều dưỡng cần giải thích, hướng dẫn, động viên giúp đỡ người bệnh và hướng dẫn cho người bệnh, người nhà cùng phối hợp để giúp đõ người bệnh trong các hoạt động sinh hoạt và giúp người bệnh tự tập được các bài tập phục hồi chức năng

Tỳ lệ người bệnh được động viên, trấn an bệnh nhân để bệnh nhân an tâm điều trị $\geq 2$ lần/tuần là $92,8 \%$, Hướng dẫn vệ sinh cá nhân sạch sẽ $\geq 2$ lần/tuần là $86,2 \%$ và Hướng dẫn chế độ đảm bảo dinh dưỡng $\geq 2$ lần/tuần là $94,9 \%$. Kết quả nghiên cứu của chúng tôi tương đồng với kết quả của Nguyễn J[6]. Tư vấn về tự vệ sinh cá nhân phòng tránh nhiềm khuẩn mắc phải, tư vấn về tự tự theo dõi phòng tránh tái phát bệnh, tư vấn về chế độ dinh dưỡng, tư vấn về vận động thể lực, tư vấn cho NB về tầm quan trọng tuân thủ chăm sóc vệ sinh cá nhân rất quan trọng trong bệnh ung thư vú, đặc biệt là vệ sinh cá nhân ngăn ngừa nhiễm khuẩn. Người bệnh cần được nằm trong buồng thông thoáng, sạch sẽ.

Điểm trung bình CLCS Chung là 61,83 \pm 12,68 , chất lượng cuộc sống về vai trò xã hội tỷ lê người bênh không ảnh hưởng đến CLCS dao động 6,5\% - 16,7\%, tỷ lệ người bệnh có ảnh hưởng đến CLCS nhiều và rất nhiều dao dộng từ $7,3 \%-81,2 \%$. Điểm CLCS trung bình chung là $55,68 \pm 22,47$ điểm; Tương đồng với kết quả của Linh Thi Tu Nguyen[5],đa số người bệnh sinh hoạt xã hội do tình trạng sức khỏe và khi mang bệnh nên người bệnh xem đây là công việc thích hợp với chính bản thân mình và họ cũng mong nhận được sự hố trợ khi cần thiết, điều đó giúp cho những người bệnh này tự tin hơn.

Đa số điểm trung bình CLCS của các khía cạnh và giữa các kết quả điều trị và chăm sóc khác nhau, có xu hướng giảm dần và có ý nghĩa thống kê. Tuy nhiên, Khía cạnh Tâm lý- cảm xúc, điểm CLCS có liên quan với đến kết quả điêu, Hoạt động thể lực, Vai trò xã hội, Khả năng nhận thức, Sức khỏe tổng quát với $\mathrm{p}<$ 0.05 kêt quả nghiên cứu của chúng tôi tương đồng với kết quả của Dahye Koh, Sihan Song et al[7]. Có thể lý giải rằng nhiều NB không chịu chấp nhận thay đổi hình thể, mang túi đựng phân dịch bên người... Những ý nghĩ về cơ thể mới làm ho phải vật lộn với những vấn đề như tâm lý, lo lắng, buồn, mặc cảm ảnh hưởng tiêu cực đến CLCS. 


\section{KẾT LUÂ̂N}

1. Đặc điểm lâm sàng, cân lâm sàng, chất lượng cuộc sống của người bệnhung thư vú đều được cải thiện sau khi nhập viện điều trị.

2. Có sự khác biệt và có ý nghĩa thống kê giữa chất lượng cuộc sống với hoạt động thể lực, vai trò xã hội, khả năng nhận thức, sức khỏe tổng quát với $p<0,05$

\section{TÀI LIÊU THAM KHẢO}

1. Đố Thị Kim Anh (2016). Đánh giá kết quả điều trị hóa chất bổ trợ phác đồ $4 \mathrm{AC}-4$ Paclitaxel trên bệnh nhân ung thư vú giai đoạn II-III. Tạp Chí Ung Thu' Hoc Viêt Nam, 1,260-26்

2. Bừi Diệu, Nguyê̂n Bá Đức, Trân Văn Thuấn và công sự (2012). Gánh nặng bệnh ung thư và chiê̂n lươợc phòng chống ung thứ quốc gia đến năm 2020. Tapp chí ung thư hoc, 1, 13-19.(1)

3. Nguyễn Văn Chủ và Lề Đình' Roanh (2015). Đănh giá mối liên quan giữa typ phân tử ung thư biểu mô tuyến vú và chỉ số tiên lươơng Nottingham (NPI). Tạp Chí Y Học TP Hồ Chí Minh, 19(5), 127133.(11)

4. Linh Thi Tu Nguyen, My Thi Tra Quach, Dung Thi Do, Ha Minh Do, To Van Ta, Thai Hong Trinh, (2015), "Novel alteration of mitochondrial tRNATrp in a group of Vietnamese breast cancer patients", Ann Transl Med, 3(S2): AB110, pp 72-73

5. Từ Quốc Hiệu, Trương Quang Vinh, Nguyến Thi Thu Phướng (2013), "Đánh giá kiến thức, thái độ, hành vi về phòng chống ung thư người dân tỉnh Bắc Giang 2012", Tạp chí ung thư học Việt Namm, 1, tr.65-71.

6. Nguyền' $J$, Popovic $M$, Chow $E$, Cella $D$ et al (2013). EORTC QLQ-BR23 and FACT-B for the assessment of quality of life in patients with breast cancer: a literature review.

7. Dahye Koh, Sihan Song et al (2015-2019). Adherence to the American Cancer Society Guidelines for Cancer Survivors and Health-Related Quality of Life among Breast Cancer Survivors.

\section{NGUYÊN NHÂN VÀ ĐĂC ĐIỂM LÂM SÀNG BÊ̂NH VIÊM NÃO Ở TRẺ EM TAII TİNH AN GIANG}

\section{TÓM TẮT}

Đắt vấn đề: Viêm não là bệnh lý nhiễm trùng hệ thân kinh trung ương thường gặp ở trẻ em, tuy nhiên rât khó xác định nguyên nhân. Mục tiêu của nghiên cứu này nhằm xác định tác nhân gẩy viêm não và mô tả đắc điểm lâm sàng và cân lâm sàng các trường hợp viêm não cấp ở trẻ em tại An Giang. Đối tượng và phương pháp: Nghiên cứu hồi cứu mô tả các trường hợp viêm não nhập viện tại Bệnh viện Sản Nhi An Giang từ tháng $1 / 2018$ đến tháng 12/2019. Để xác định các tác nhân gây viêm não, các mâu dịch não tủy được làm PCR để tìm Enterovirus và Herpes simplex, làm kỹ thuật Elisa tìm kháng thể IgM kháng virut dengue và virut gây viêm não Nhât bản. Kết quả: Trong 2 năm có tất cả 45 trẻ em từ 6 tháng-14 tuổi bị Viêm não. Tỉ lệ xác định được tác nhân gây bệnh là 26,6\% trong đó Viêm não Nhật bản (VNNB) B (6 ca), Enterovirus $(4 \mathrm{ca})$ và Herpes simplex $(2 \mathrm{ca}) .73,4 \%$ không xác định được tác nhân gây bệnh. Triệu chứng lâm sàng thường gặp gồm: sốt, ói, co giật, biến đổi tri giác và dấu thẩn kinh định vị. Các trường hợp xác định nguyên nhân thường ít có triệu chứng co giật, số lượng bạch cầu máu, tî lệ neutrophile và nồng độ lactat trong dịch não tủy cao hơn. Cả 2 trường hợp viêm não do Herpes simplex đều có biểu hiện nặng

${ }^{1}$ Dai học Y Dược Cần Thơ

²Bệnh viện Sản Nhi An Giang

Chịu trách nhiệm chính: Nguyễn Ngọc Rạng

Email: nguyenngocrang@gmail.com

Ngày nhận bài: 26.10.2020

Ngày phản biện khoa họ: 30.11 .2020

Ngày duyệt bài: 11.12.2020

\section{Nguyễn Ngọc Rạng1, Dương Thanh Long²}

gồm hôn mê, co giật và liệt nưa người. Kết luân: Viêm não Nhật bản B và Enterovirus là 2 tác nhân hay găp nhất viếm não hiện nay tai An Giang. Mặc dù viêm não do Herpes simplex khổng gặp nhiều nhưng có biểu hiện lâm sàng nặng và tử vong cao.

Tư khóa: Viêm não, trẻ em, Herpes simplex

\section{SUMMARY}

\section{ETIOLOGIES AND CLINICAL CHARASTERISTICS OF CEPHALITIS IN CHILDREN OF AN GIANG PROVINCE}

Background: Encephalitis is a common infection of the central nervous system in children, but it is difficult to identify the cause. Objectives: To study the etiology of viral encephalitis and to describe the clinical and paraclinical characteristics of viral encephalitis in children of An giang province. Subjects and Methods: A retrospective study describing cases of encephalitis hospitalized at the Woman and Children Hospital of An Giang from January 2018 to December 2019. To identify the causative agents of encephalitis, PCR was performed from CSF to diagnose of Enterovirus and Herpes simplex; Mac-Elisa was performd to diagnose of Dengue and Japanese encephalitis. Results: 45 patients from 6 months to 14 years olds, were enrolled in the study. The etiology of viral encephalis was determined in 26,6 \% patients including Japanese encephalitis ( 6 cases), Enterovirus (4 cases) and Herpes simplex ( 2 cases). The most common signs and symstoms were: fever, vomit, convulsion, disturbance of consciousness and localizing neurologic signs. The children with positive diagnosis of viral 